WE have just received advices on going to press that cholera has appeared at Antwerp and Rotterdam, and that at the former port fifteen deaths out of a total of thirty cases have occurred.

Thanks to the autumnal frosts, the yellow fever is abating at Memphis. The city is desolate, and additional relief is urgently called for. At Shreveport the fever is declining.

Messrs. Barraud and Jerrard have forwarded for our inspection a photographic portrait of the late Sir Henry Holland. It is in every way a faithful likeness.

Dr. Cutchiffe, well known throughout the Bengal Presidency, died last week.

\section{A NEW REFRIGERATING APPARATUS.}

Captain Frederick WarRen, R.N., the inventor of the now famous "cooking-pot," proposes to apply to many useful purposes the ice-making and refrigerating apparatus for which the patent is now held by Messrs. Siebe and West, of Mason-street, Lambeth. The invention is based upon the production of cold by the rapid evaporation of a volatile liquid-a phenomenon with which all who use the condensed nitrous oxide gas must be familiar, for as that agent is allowed to escape the cold produced by its resuming the gaseous state is so intense as to cause the moisture of the atmosphere to be deposited as ice upon the tap of the bottle.

Last week, at the factory of the patentees, we had an opportunity of witnessing the apparatus in action. Its construction is such that by means of an air-pump methylated ether is rapidly vapourised in one chamber, whilst th vapour is passed into another chamber, there to be condensed ready for re-evaporation. In this way, by the repeated evaporation of the same condensed ether, cold is pro duced to a degree only limited by the steam power employed in working the pump; and, as the ether is throughout contained in hermetically closed vessels, waste is ensured against. Regard is had to its required application in uti lising the great cold obtained in the ether evaporating chamber, or refrigerator. 'Thus, for ice-making, a continuous current of brine (used on account of its uncongealable nature) is passed through pipes in the refrigerator, and having been so cooled is caused to circulate, at a temperature below zero, between the metallic vessels which contain the fresh water to be frozen, and then back to the refrigerator, there to be recooled.

From this description it will be seen that the freezing process is self-regulating and continuous, depending for its perfection upon the application of sufficient power to drive the air-pump, and to circulate the brine. Captain Warren's adaptation of the apparatus is to drive air through tubes, around which the cold brine is circulating, so that cooled it may be supplied to railway carriages in hot climates, to the stoke-holes of steam-vessels, to hospital wards, and to chambers wherein fresh meat and vegetables are stored. That this can be done we are convinced, for during our visit the air was drawn from the chamber in which the experiment was conducted, and immediately returned $20^{\circ} \mathrm{Fahr}$, cooler. The hygienic value of such an application of the refrigerating apparatus is patent, and the results which would follow its adoption in our tropical hospitals are not likely to disappoint the anticipations of its most sanguine advocates. The economy of the process is obvious when we recollect that, beyond the prime cost for plant, only a small allowance of manual and steam power is required to produce blocks of clear ice in any climate; a comfort for the invalid and a luxury for all resident in the tropies which, until the present time, has been practically unknown; for though there have been freezing-machines, nothing of the kind before this was satisfactory; the majority required ammonia, and quickly became useless or dangerous, owing to the destructive action of that agent on metal. That the cold draught might be advantageously applied in the conveyance of meat from Aberdeen to London, Captain Warren is confident. Moreover that it might be employed to enable a man-of-war to carry fresh provisions for all hands for twenty-eight days, in which case it would prove a substantial boon to the navy. But he does not believe in the practicability of bringing home entire cargoes of meat in ice from Australia and other distant parts, either by his own or any other mothod.

\section{HEALTH OF THE NAVY.}

The Report of the Medical Director-General of the Navy for the year 1871 has just been issued from the Queen's Printing-office, and has many items of special as well as of general interest. The total force during the year under consideration consisted of $45,460 \mathrm{men}, 50^{\circ} 04$, per cent. being between the ages of fifteen and twenty-five, 35.61 between twenty-five and thirty-five, 11.66 between thirtyfive and forty-five, 250 between forty-five and fifty-five, and 16 between fifty-five and sixty-five. These age-tables appear in this Report for the first time, will continue to be furnished to the officers on all the stations, and will obviously form in the future very important data as to the general health of the force afloat.

During the jear 1871,57,231 cases of disease and injury were under treatment, being in the ratio of 1210.9 per 1000 of force, a decrease, as compared with the preceding year, equal to 12.1 per 1000 . A total of 1523 men were invalided, representing a comparative decrease of $3 \cdot 2$ per 1000, and the deaths numbered 404 , representing 8.5 per 1000 of force, the mortality being precisely the same as in the previous year, deductions being made on account of the lamentable losses of the Captain and Slaney in 1870 .

In consequence of the great prevalence of small-pox in the United Kingdom, a general revaccination of all the men and boys in the service was ordered and carefully carried out. The Report includes a specially interesting account of dengue as it occurred at Aden, on cases of heatstroke and sun-stroke in the Persian Gulf, and a history of the march of cholera from some of the large famine-stricken towns of Central Persia to the Persian Gulf, where it unhappily was imported into one of the ships of the squadron. The North-American and West-Indian stations were happily almost exempt from yellow fever, but enteric fever continued, as before, to infect nearly all the Mediterranean seaports, Malta being specially emphasised. It speaks well for the hygienic measures adopted and maintained in her Majesty's naval forces that, out of a total of 47,460 men, only four cases of scurvy occurred during the year under consideration, three of these being Kroomen, a race easily affected by debilitating causes.

There are many special items of interest to which we shall refer in future reports, but it is a duty to the Director-General to record that the Report of 1871 appears to have been compiled with unusual skill and ability, and that the vast amount of information contained in it is more cleverly summarised, the result, as we may divine, of the indefatigable exertions of Dr. Mackay.

\section{Cortespondente.}

"Audi alteram partem."

\section{HEALTH OFFICERS AND "QUARTERLY RETURNS."}

To the Editor of THE LANCET.

SIR,-I read with some interest the letter on this subject in your issue of to-day, inasmuch as our able and energetic medical officer of health (Dr. Mackintosh) called on me yesterday, asking me to furnish him with a report of the number of cases of in- and out-patients treated at the Chesterfield and North Derbyshire Hospital, with the 
diseases and injuries, ages, and causes of death for the quarter ending 30th September last. As a friend, I had great pleasure in complying with his request, although the compilations took us about an hour and a half.

But I maintain it is unfair on the part of Government to expect us to give valuable information and vital statistics of this kind gratuitously, and that provision should be made by Act of Parliament for the payment of a moderate fee.

I send this letter solely in the interests of the profession, and especially of my junior brethren, who may be resident medical officers, and who may have no income but the small and very inadequate salaries generally attached to these appointments. No profession does so much gratuitous work for the benefit of the public as our own, and this I think is universally acknowledged. But there is a limit, and I think we should not encourage, or quietly submit to, shabby and illiberal treatment on the part of the Government. Indeed, it would be suicidal and an act of pusillanimity to do so without remonstrance. I wish we had more medical men in the House of Commons; and I think at least one or two of the élite of the profession should be members of H.M.'s Privy Council, from which, as far as I am aware, the medical element is entirely excluded.

This is, indeed, one of the great wants of the age, and imperatively demanded in the interests of the profession, as well as for the promotion and proper handling of the allimportant subject of sanitary legislation.

Should you agree with what I have said in this note, $I$ am sure your powerful aid will not be wanting.

I am, Sir, yours faithfully,

Chesterfield, October 25th, 1873. JoHN Rose, M.D.

\section{To the Editor of The LaNCET.}

Sir,-The Local Government Board are applying to the medical officers of health for information which they must well know can only be obtained from the union medical officers. I beg to suggest the following as the proper mode of reply to medical officers of health on the subject:-

"Dear Sir,-I must decline to furnish the returns you require. If the sanitary authority will grant me some fair remuneration annually, and thus place me in that position which it was intended by $\mathrm{Mr}$. Stansfeld and others at the very outset of the Public Health Act I should occupy by virtue of my office, I shall be happy to furnish you with any returns you may require, and also give that assistance in preventing the occurrence and spread of epidemic disease, and such like service, which I have great opportunity of doing in my capacity of union medical officer.-I am, \&c."

As a matter of principle I think we should give all assistance in our power or none at all; which it will be must depend on the action of the Local Government Board.

I am, Sir, yours \&c.,

Union Medical Officer.

Worcester, October 17 th, 1873.

\section{A NEW FIELD FOR HOSPITAL PRACTICE.}

\section{To the Editor of THE LANCET.}

SIR,-In this week's issue of your excellent journal you have proposed a scheme of out-door medical relief which is apparently capable of such beneficial results, and of being conducted at so small a pecuniary expense, that it seems incredible it should never have been before publicly suggested. The importance of efficient out-door medical relief from hospitals cannot be overrated, especially in the large towns. Charitable medical treatment, in London especially, is too scanty and remiss, and everyone conversant with the subject must feel that it is high time to organise a system of relief that will be co-extensive with the evil, but which may be so strictly supervised as to prevent injury or abuse. It is a mere evasion of a very serious fact to say that we ought rather to encourage providence among the poor than to favour pauperism. But seeing that we have poverty and disease amongst us, it behoves us as medical men to attack them, and to mitigate their evils, leaving it to others to supply proper means for their eradication. Doubtless the proposal will not meet with unqualified approval, and may even be stoutly opposed by some; but on the first blush it appears that the advantage to the medical student and the benefit to the parochial medical officer will be inestimable. It may be asserted that such a system may inflict a considerable amount of injury on the medical men who practise among the poor, but I think that if the facts be taken at their real worth it will be found a blessing to them. How many patients do such practitioners see during the course of a year for which they know that they will never receive any remuneration! To rid them of this unprofitable labour must therefore be a real boon, while the supervision that you hint at will be sufficient to prevent undeserving persons partaking of the benefits of the charity. As a minor suggestion, it may be said that to insist on a small payment for medicines would in some cases be desirable, and might act as a salutory check.

Oct. 28th, 1873.

I am, Sir, yours truly,

A Hospital Surgeon.

\section{NAVAL ASSISTANT - SURGEONS.}

To the Editor of THE Lancet.

Srr,-I desire to ask you to advocate the cause of those unfortunate naval surgeons who have been refused their resignations, and to whom there now exists no hope except through your powerful advocacy. Our case is one of exceeding hardship, and one calling loudly for redress. I myself believe, in common with a great many others, that the action of the Admiralty is illegal ; but we have been all sent on foreign service, and are consequently prevented from trying the matter in a court of law. The only course now open to us is either to desert or else commit some act for which we can be tried by court martial and dismissed the service; but I need hardly tell you, Sir, that this last expedient is one which every man having any pretensions to be a gentleman would hesitate before adopting, not only as bringing disgrace upon himself, but also upon a noble and honourable profession. As far as I am personally concerned, I have done all that man can do by fair means to leave the service. I have over and over again sent in my papers asking for leave to retire, and have each time been peremptorily refused. I informed their lordships that I was quite willing to refund any expense the country had incurred during my residence at the Army Medical School I also told them that sea-sickness rendered me utterly incapable of performing my duties while at sea; but all my remonstrances have been unavailing, and I must either quietly submit, or else disgrace myself and ruin all prospect of future professional advancement. Such, then, is a brief outline of our present position. We find that, allured into the service by false promises, and having found out our mistake, it is impossible to leave the navy until we have wasted the best days of our life, or, as Mr. Goschen said in the House of Commons, "until by good and long service we show ourselves worthy of the indulgence." A common sailor or soldier can buy his discharge, and executive and other officers are well paid for leaving the service, but a surgeon is compelled, as Sir D. Corrigan truly quotes in his able letter of the 9th August, to "all hope abandon ye who enter here."

Oct.10th, 1873. I am, Sir, yours truly, Justitia.

\section{BIRMINGHAM.}

(From our own Correspondent.)

THE clinical work of the General and Queen's Hospitals is this session for the first time made available to the students for a common fee, and conducted under the superintendance of a clinical board, consisting of Dr. Bell Fletcher, chairman, and Drs. Wade and Foster, and Mr. Oliver Pemberton, as representatives of the former; and Dr. Johnston, and Messrs. West and Wilders, as representatives of the latter hospital. The new students, who already number thirty-six, will be divided equally between the two hospitals, and will receive clinical instruction at 